OCCUPATIONS OF THE PEOPLE OF GREAT BRITAIN, 1801-1981 
Also by Guy Routh

ECONOMICS: An Alternative Text

OCCUPATION AND PAY IN GREAT BRITAIN, 1906-79

THE ORIGIN OF ECONOMIC IDEAS

UNEMPLOYMENT: Economic Perspectives 


\section{Occupations of the People of Great Britain, 1801-1981}

Guy Routh

with a Compendium of a Paper 'Occupations of the People of the United Kingdom, 1801-81' by Charles Booth 
(1) Guy Routh 1987

Softcover reprint of the hardcover 1st edition 1987 978-0-333-43497-0

All rights reserved. No reproduction, copy or transmission of this publication may be made without written permission.

No paragraph of this publication may be reproduced, copied or transmitted save with written permission or in accordance with the provisions of the Copyright Act 1956 (as amended), or under the terms of any licence permitting limited copying issued by the Copyright Licensing Agency, 33-4 Alfred Place, London WC1E 7DP

Any person who does any unauthorised act in relation to this publication may be liable to criminal prosecution and civil claims for damages.

First published 1987

Published by

THE MACMILLAN PRESS LTD

Houndmills, Basingstoke, Hampshire RG21 2XS

and London

Companies and representatives

throughout the world

British Library Cataloguing in Publication Data

Routh, Guy

Occupations of the people of Great

Britain, 1801-1981.

1. Great Britain - Occupations - History

I. Title II. Booth, Charles. Occupations

of the people of the United Kingdom, 1801-81

331.7 '00941 HD8389

ISBN 978-1-349-09276-5 ISBN 978-1-349-09274-1 (eBook)

DOI 10.1007/978-1-349-09274-1 


\section{Contents}

List of Tables and Figures

vii

Preface

ix

Introduction

xi

1 Charles Booth, 'Occupations of the People of the United Kingdom, 1801-81'

1.1 General review of occupation censuses

1.2 The occupations of the people considered

2 1881-1911

3 1911-1951

3.1 Occupational classes $\quad 25$

3.2 Occupational class structure, 1911-51 27

3.3 The incidence of change 29

4 1951-1981 35

4.1 Census changes $\quad 35$

4.2 Manual and non-manual workers 36

4.3 Occupational classes 1951, 1971, $1981 \quad 37$

4.4 Distribution by status, 1981

4.5 Changes within classes 41

5 Retrospect $\quad 50$

5.1 History unfolding $\quad 50$

5.2 The growth of population 56

5.3 Agriculture and growth 58

5.4 Textiles, engineering, railways, coal 61

$\begin{array}{lll}5.5 & \text { The professionals } & 67\end{array}$

5.6 The office workers $\quad 73$

5.7 Pay patterns $\quad 77$

5.8 Directions after $1981 \quad 81$ 
vi

Contents

6 Britain in its World Setting

6.1 Partners and Competition

6.2 The British position

Appendix: Allocation of 1981 Occupational Units to Occupational Classes

Bibliography

Index
85

85

88

89

95

97 


\section{List of Tables and Figures}

Tables

1.1 Occupations of the people of Great Britain, 1841-81

1.2 Changes in the employment of women aged over 15, England and Wales, 1851-81

1.3 Employments of the people by percentage, England and Wales, 1851-81

1.4 Increase of population, with changes in numbers supported by agriculture, England and Wales, 1801-81

1.5 Employments of the people by percentage, Scotland, 1851-81

2.1 Analysis of the occupied population, Great Britain, 1881-1911

2.2 Women as \% of labour force, 1881-1911

2.3 Increase in clerks, by category, 1881-1911

3.1 Occupied population by occupational class, Great Britain, 1911, 1921, 1931, 1951

4.1 Distribution of manual and non-manual workers, census years $1951-81$

4.2 Occupational classes by sex, 1951, 1971, $1981 \quad 38$

4.3 Occupational class and industrial status by sex, 1981

4.4 Skilled manual workers, 1951-81

4.5 Semi-skilled manual workers, 1951-81

4.6 Unskilled manual workers, 1951-81

5.1 The total and occupied populations of England, Wales and Scotland, 1801 or 1802

5.2 Wage rates and the cost of living 1801-1981

5.3 Total population, numbers and percentage economically active, and percentage employed in agriculture, 1801-1981

5.4 Index of production for agriculture, forestry and fishing, 1801-1981

5.5 Employment in four industries, 1841-1981

5.6 Percentage of United Kingdom exports provided by textiles, metal-making and -using, coal and chemicals in various years, 1911-71

5.7 Indexes of output and output per worker in textiles, 
mining and quarrying, and metal-making and -using, 1861-1981

5.8 Numbers and proportions of professionals (higher and lower), 1841-1981

5.9 Numbers in the higher professions, 1911 and 1981

5.10 Engineers, scientists, architects, surveyors and ship designers, numbers and percentage changes 1911-81

5.11 Numbers in the lower professions, 1911 and 1981

5.12 Clerical workers, 1881-1981

5.13 Civil service pay, 1876-1913

5.14 Average pay of men and women by occupational class, 1978, and factor of increase since 1913-14

5.15 Equivalent of one male higher professional in other occupations, 1913-14 and 1978

5.16 Percentage distribution of men and women between occupational classes in the New Earnings Survey, April, 1981 and 1985

5.17 Percentage distribution between occupational classes, April 1981

6.1 Occupied population by occupational group in various countries in the early $1980 \mathrm{~s}$

Figures

2.1 Distribution of employment by occupational order, Great Britain, 1881-1911

2.2 Distribution of employment within manufacturing industry, Great Britain, 1881-1911 


\section{Preface}

Charles Booth (1840-1916) was celebrated in his day and is remembered in ours for his Life and Labour of the People in London. It was in that great enterprise that Beatrice Webb, his cousin by marriage, served her apprenticeship. She afterwards remarked, 'the grand inquest into the conditions of life and labour of the four million inhabitants of the richest city in the world - an investigation carried on by Charles Booth (entirely at his own expense) over a period of seventeen years and published in as many volumes - seems to me to stand out as a landmark alike in social politics and in economic science' (Beatrice Webb, 1926, p. 226).

On 18 May 1886 Booth presented a paper to the Statistical Society (it had not yet been granted its Royal Charter) under the title of 'Occupations of the People of the United Kingdom, 1801-81'. The centenary of its presentation seems a good time to extend the survey to 1981. For the period 1911-71, I draw on a book published some years ago (Routh, 1980) which I now extend to incorporate the results of the census of 1981 . For the intervening years, I pick up the story where Booth left it and carry it on to the point where I began.

Booth's paper of 1886, which is reproduced as Chapter 1 of this book, demonstrates how much can be deduced, and rightly deduced, from the careful assembly and consideration of census data:

We know that Manufacture was then [in 1801] an adjunct of Agriculture, and that a hundred things were made at home for which everyone now goes to a shop; we know that machinery and commerce have changed this, and we see the end of the period of revolution in the amazing figures of change between 1841 and 1851 , when the furthest point of unrestricted competition was reached, and when the reaction towards socialism commenced with the Factory Acts; but it is only of the period since 1851 that the census figures enable us to speak with any accuracy (see Chapter 1 below, p. 12).

Nowadays, of course, we have an abundance (some might say a superabundance) of figures. It is difficult to keep up with them, and still more so to interpret them correctly, tasks that I hope this book will do something to facilitate.

GuY RouTH 


\section{Introduction}

A worker's job consists of a set of duties that he or she is required to perform. Nowadays, they may be formalised in a written job description, but more generally they are defined by custom and practice. Jobs with similar characteristics are grouped into occupations. In an industry many jobs are assembled in that variety of occupations necessary to process the materials and produce the products by which it is characterised. Whether we take the viewpoint of job, occupation or industry, the process we observe is one of work which, in Booth's words, consists of 'the turning of raw materials into things serviceable' (see Chapter 1 below, p. 13), or, in the words of Eugen Loebl, 'the transformation of natural forces into useful forces, natural goods into useful goods'. 'The source of wealth thus lies in the degree to which we are able to transform and control natural forces, and this, in turn, is a direct result and a function of our ability to think and to create' (Loebl, 1976, p. 22).

In pre-capitalist societies innovation was regarded with suspicion. It still is in subsistence economies of the present day. When people live from hand to mouth, it is safer to rely on methods proved by practice and preserved by tradition. There is no end of cases where the bright ideas of townspeople, backed by government authority, have resulted in disaster. But the riches of the mercantile revolution brought with them scope for experiment. The variety of occupations expanded both with the invention of new products and the division of labour for the production of traditional ones. At the turn of the seventeenth century, Boisguillebert remarked on the growth of opulence: 'in the infancy or innocence of the world man's simple needs were procured by the pursuit of only three or four occupations; now there are more than two hundred, with more invented every day' (Boisguillebert, 1843, pp. 403-4). In 1861, the census authorities in London prepared a dictionary of occupations; by 1911, it contained 'upwards of 30,000 different terms' (Census of England and Wales 1911, vol. X, p. ix, Cd 7018, 1914).

The advent of the industrial system did not make work easier for the majority of workers. In agriculture they were required to work very hard at certain times of the year, in particular for planting and harvesting, but these were interspersed by periods when there was not much to do, and this lent variety to their lives. As the Industrial 
Revolution proceeded, farm labour was replaced by work in factories and mines, where girls and boys, men and women were required to work for twelve or fourteen hours a day, six days a week.

Adam Smith, who in Book I of The Wealth of Nations had hailed the division of labour as the prime instrument of progress, in Book $\mathrm{V}$ warned of its evil implications:

In the progress of the division of labour, the employment of the far greater part of those who live by labour, that is, of the great body of the people, comes to be confined to a few very simple operations; frequently to one or two. But the understandings of the greater part of men are necessarily formed by their ordinary employments. The man whose whole life is spent in performing a few simple operations, of which the effects too are, perhaps, always the same, has no occasion to exert his understanding, or to exercise his invention in finding out expedients for removing difficulties which never occur. He naturally loses, therefore, the habit of such exertion, and generally becomes as stupid and ignorant as it is possible for a human creature to become. The torpor of his mind renders him, not only incapable of relishing or bearing a part in any rational conversation, but of conceiving any generous, noble, or tender sentiment, and consequently of forming any just judgment concerning many even of the ordinary duties of private life... His dexterity at his own particular trade seems, in this manner, to be acquired at the expence of his intellectual, social, and martial virtues. But in every improved and civilized society this is the state into which the labouring poor, that is, the great body of people, must necessarily fall, unless government takes some pains to prevent it.

(Adam Smith, 1776, pp. 781-2)

This was the state into which the labouring poor did indeed fall. Almost another century had to pass before compulsory education was introduced in England, while long struggles were waged to reduce hours and improve conditions of work, to raise wages and, eventually, to introduce pensions and sick and unemployment insurance. But all this time, a silent evolution was occurring that, when foreshortened by historical narration, assumes the appearance of a revolution. The labouring poor, for the first part of the nineteenth century, were held in a trap that left them little or no initiative and no means of escape. Sons and daughters followed fathers and mothers 
into coal-mines, textile factories or domestic service, with poverty now substituted for the feudal obligations of previous days. But erratically and slowly the boundaries of choice did expand.

The railways brought new jobs as well as possibilities of travel, the engineering industry offered new opportunities for the learning and exercise of skills. Restrictions on women's employment were eased by the expansion of nursing and teaching and, in the closing decades of the century, their entry into office work, aided by the invention of the typewriter. In the twentieth century there came substantial increases in the numbers of scientists and engineers, medical auxiliaries, draughtsmen and technicians. This book offers a measure of the extent of the transformation and the pace at which it has advanced, the data having been drawn mainly from the occupational tables of the censuses of population.

These censuses have been held every ten years, in the first year of each decade, beginning in 1801 and excepting 1941. As is to be expected, they have varied in quality and scope. In 1801, three occupational classes were distinguished: (1) agriculture, (2) trade, manufactures and handicrafts, and (3) the rest, with enumerators also required to report the numbers of army and navy personnel, merchant seamen, and convicts awaiting transportation. In 1811, the authorities decided that families were more important than individual workers: how many families were there whose existence depended on income derived from agriculture or trade, manufactures and handicrafts, or something else?

In 1841 there was an important organisational change: the task of enumeration was transferred from parish overseers, clergymen or schoolmasters to the recently established Registrars of Births and Deaths. Each householder was now required to complete a schedule under the supervision of enumerators appointed by the Registrars. 'These schedules were copied into books which were transmitted to the Census Office, where the work of classifying the occupations from the information supplied by the people themselves was carried out under definite rules and on uniform lines for the whole country' (Census of England and Wales 1911, vol. X, p. vi). The authorities were overwhelmed. In cotton manufacture alone 1255 different titles were returned. With attempts at classification abandoned, these were listed under the heading, 'Cotton manufacture, all branches'. Even so, the report ended up with 877 occupational headings, presented in alphabetical order with no attempt at further analysis.

In 1851 , order was introduced by the allocation of occupations to 
17 classes and 91 sub-classes. The dictionary of occupational terms in 1861 showed their allocation to 'Orders' and 'Sub-orders' (ibid., p. vi). The agonising continued over the principles by which classification should be applied. A report to the Registrar General proposed that the criterion should be the substance on which the work was performed, so that persons working and dealing in animal substances were differentiated from those working and dealing in vegetable substances, mineral substances and so on (Appendix by W. Farr to the Census Report, 1861, p. 232).

It was not until 1911 that a solution emerged: there had to be two sets of tables, one classifying the occupied population by occupation (the sort of work performed), the other by industry (the end product by the relevant establishment). In 1921, this separation was more precisely established, and has since formed the basis of those census tables dealing with economic activity.

In 1911, there was another important innovation: every occupation was allocated to one of five social classes, a system that you will find elaborated in section 3.1 below. This was related to the Registrar General's analysis of occupational mortality (begun in 1851) and fertility (1911). Children per family do indeed vary significantly with social class, as does the expectation of life.

The classification system of 1921 marked a great step forward, but the difficulties of those working with census data were not over. The high-point of the census-taker's art was reached in 1951. In 1961, 1966 (an experimental sub-census) and 1971, the number of occupations distinguished was drastically reduced, while in 1961 the distinction between employer and manager was dropped (as it had been in the report of 1931). The distinction was reasserted in 1966, and, in 1981, the number of occupations was increased to 549 (still below the 584 units of 1951). In future, we may at least hope for consistency, if not perfection, for the Office of Census is committed to the Department of Employment's Classification of Occupations and Directory of Occupational Titles (CODOT), changes to which require the agreement of a number of departments. The system is explained in the Office of Population Censuses and Surveys, Classification of Occupations and Coding Index (HMSO, 1980). 